(c) American Dairy Science Association, 2005.

\title{
The Effects of Various Antifungal Additives on the Fermentation and Aerobic Stability of Corn Silage
}

\author{
D. H. Kleinschmit, R. J. Schmidt, and L. Kung, Jr. \\ Department of Animal and Food Sciences, University of Delaware, Newark 19717
}

\section{ABSTRACT}

In 2 consecutive years, whole plant corn was ensiled in laboratory silos to investigate the effects of various silage additives on fermentation, dry matter (DM) recovery and aerobic stability. In yr 1, chopped forage was treated with 1) no additive (untreated, U), 2) Lactobacillus buchneri 40788, $4 \times 10^{5} \mathrm{cfu} / \mathrm{g}$ of fresh forage (LLB4), 3) L. buchneri 11A44, $\left.1 \times 10^{5} \mathrm{cfu} / \mathrm{g}(\mathrm{PLB}), 4\right)$ Biomax 5 (Lactobacillus plantarum PA-28 and K-270), $1 \times 10^{5} \mathrm{cfu} / \mathrm{g}$ (B5), 5) Silo Guard II (sodium metabisulfite and amylase), $0.05 \%$ of fresh forage weight (SG), 6) a buffered propionic acid-based additive, $0.1 \%$ (Ki-112), 7 ), sodium benzoate, $0.1 \%$ of fresh weight (SB), or 8 ) potassium sorbate:EDTA (1:1), $0.1 \%$ of fresh weight (PSE). Silage treated with LLB4 had the highest concentration of acetic acid compared with other treatments, and yeasts were undetectable in LLB4 $\left(<\log _{2}\right.$ $\mathrm{cfu} / \mathrm{g})$. Silages treated with SB and PSE had the highest concentrations of water-soluble carbohydrates, the greatest recoveries of DM, and the lowest concentrations of ethanol. Silages treated with B5, SG, and Ki112 had no effects on fermentation, DM recovery, or aerobic stability. The aerobic stabilities of silages treated with LLB4, SB, and PSE were greatest among all treatments. In yr 2, treatments were: 1) U, 2) LLB4, 3) PLB, 4) PLB at $4 \times 10^{5} \mathrm{cfu} / \mathrm{g}$ (PLB4), and 5) B5. Silages treated with $L$. buchneri had greater concentrations of acetic acid but lower concentrations of ethanol than did U- and B5-treated silages. Yeasts were undetected in all silages except in silage treated with B5, which had the poorest aerobic stability of all treatments. Treatments had no effect on DM recovery. Silages treated with PLB, PLB4, and LLB4 remained stable for $>210 \mathrm{~h}$. (Key words: Lactobacillus buchneri, aerobic stability, corn silage)

Abbreviation key: B5 $=$ Biomax 5, added to achieve $1 \times 10^{5} \mathrm{cfu} / \mathrm{g}$ of fresh forage weight, Ki-112 = a buffered propionic acid-based additive,added at $0.1 \%$ of fresh forage weight, LLB4 = Lactobacillus buchneri 40788,

Received September 3, 2004.

Accepted January 26, 2005.

Corresponding author: Limin Kung, Jr.; e-mail: lksilage@udel.edu.
$4 \times 10^{5} \mathrm{cfu} / \mathrm{g}, \mathbf{P L B}=$ L. buchneri $11 \mathrm{~A} 44,1 \times 10^{5} \mathrm{cfu} / \mathrm{g}$, PLB4 = L. buchneri $11 \mathrm{~A} 44,4 \times 10^{5} \mathrm{cfu} / \mathrm{g}, \mathbf{P S E}=$ potassium sorbate (50\%)-EDTA $(50 \%)$ additive, $0.1 \%, \mathbf{S B}=$ sodium benzoate, $0.1 \%, \mathbf{S G}=$ SiloGuard II, $0.05 \%, \mathbf{U}=$ untreated corn silage, WSC $=$ water-soluble carbohydrates.

\section{INTRODUCTION}

Silages with poor aerobic stability can be found on many dairies because of slow filling rates or inadequate packing densities at the time of ensiling. In addition, removal of inadequate amounts of silage during feedout and poor management at the face of the silo exposes the silage mass to prolonged contact with air. Consequently, lactate-assimilating yeasts (e.g., Candida, Endomycopsis, Hansenula, and Pichia; Woolford, 1990) degrade lactic acid to carbon dioxide and water and produce excessive heat that leads to a loss of nutrients. Degradation of lactic acid also increases the $\mathrm{pH}$ of the silage to a level that allows opportunistic bacteria (e.g., Bacilli; McDonald et al., 1991) and molds (e.g., Aspergillus, Fusarium, and Penicillium; McDonald et al., 1991) to grow and further reduce silage quality. Besides an economic loss of nutrients, feeding spoiled silage to ruminants depresses nutrient intake and decreases production (Hoffman and Ocker, 1997; Whitlock et al., 2000).

To address the problem of aerobic instability in silages, various chemical additives with antifungal properties have been evaluated. For example, buffered propionic acid-based additives applied at 0.2 to $0.3 \%$ of fresh forage weight have improved the stability of corn silage (Kung et al., 1998, 2000). However, these studies found the current commercial application rate $(0.1 \%$ of fresh forage weight) of these additives to be inadequate at improving aerobic stability. Both sodium benzoate and potassium sorbate are common food additives that have been effective at inhibiting the growth of yeasts and molds (Woolford, 1975) and improving aerobic stability in silages (Alli et al., 1985; Lingvall and Lattemae, 1999). The undissociated form of these salts pass through the cell membranes of yeasts and molds and release their protons into the cytoplasm, thereby acidifying the intracellular region (Buxton et al., 2003). So- 
dium metabisulfite has also been studied to improve the aerobic stability of silages; however, it was found to be ineffective (Soderlund et al., 1983; Bolsen et al., 1985).

Only a few microbial inoculants have been specifically designed to improve the aerobic stability of silages. For example, in a series of studies, cell-free fermentation extracts from $L$. plantarum PA-28 and K-270 inhibited the growth of spoilage yeasts from corn silage (Chr. Hansen's Biosystems, Milwaukee, WI). Muck (1996) suggested that Lactobacillus buchneri could improve the aerobic stability of silages, and several recent studies have shown marked improvements in aerobic stability in silages treated with this organism (Driehuis et al., 2001; Adesogan et al., 2002; Taylor et al., 2002). There are 2 strains of L. buchneri, 40788 and 11A44, commercially available in the United States and they have different suggested rates of application $\left(4 \times 10^{5}\right.$ and $1 \times 10^{5} \mathrm{cfu} / \mathrm{g}$ of fresh forage weight for $L$. buchneri 40788 and 11A44, respectively). The effectiveness of these microbial inoculants may vary from year to year (Muck, 2004) so repeated testing of these inoculants may be appropriate.

The objective of yr 1 was to determine the effect of various antifungal chemical and microbial additives on the fermentation products, DM recovery, numbers of yeasts, and aerobic stability of corn silage. The objective of yr 2 was to evaluate the effect of the microbial additives used in yr 1 on the fermentation products, DM recovery, numbers of yeasts, and aerobic stability of corn silage.

\section{MATERIALS AND METHODS}

\section{Ensiling Procedure for Year 1}

Whole plant corn, cultivar Agway 657 (Agway Inc., Syracuse, NY), was harvested at the one-quarter milk line and 28.9\% DM using a New Holland FP230 (New Holland, PA) pull-type harvester equipped with a mechanical processor. Roller clearance was set at $3 \mathrm{~mm}$ with a theoretical length cut of $19 \mathrm{~mm}$. Chopped forage was divided into 8 piles (75 kg each). The following treatments were applied to a pile of fresh forage: 1) untreated (U), 2) Lactobacillus buchneri 40788 (Lallemand Animal Nutrition, Milwaukee, WI) applied at 4 $\times 10^{5} \mathrm{cfu} / \mathrm{g}$ of fresh forage weight (LLB4), 3) L. buchneri 11A44 (Pioneer Hi-Bred, Intl., Des Moines, IA) applied at $\left.1 \times 10^{5} \mathrm{cfu} / \mathrm{g}(\mathbf{P L B}), 4\right)$ Biomax 5, L. plantarum PA28 and K-270, (Chr. Hansen Biosystems, Milwaukee, WI) applied at $1 \times 10^{5} \mathrm{cfu} / \mathrm{g}($ B5) $)$ 5) SiloGuard II, sodium metabisulfite and amylase enzyme, (International Stock Food Corp., Marietta, GA) applied at $0.05 \%$ of fresh forage weight (SG), 6) Ultra Curb, a buffered propionic acid-based additive, (Kemin Industries, Des
Moines, IA) applied at $0.1 \%$ (Ki-112), 7) sodium benzoate applied at $0.1 \%$ (SB), and 8) potassium sorbate, $50 \%$ and EDTA, 50\% applied at $0.1 \%$ (PSE). The commercial additives (2 to 6 ) were applied at their commercial application rates and the experimental additives (7 and 8) applied at rates commonly used in previous studies (Buxton et al., 2003). Treatments 7 and 8 were used as positive controls in this study. To add the targeted amount of lactic acid bacteria, all inoculants were plated on Rogosa SL agar (Difco-248020, Becton Dickinson, Sparks, MD) and an appropriate amount was used to achieve the desired application rate based on the measured concentration of lactic acid bacteria. This practice was implemented because concentrations of lactic acid bacteria in the inoculants may not accurately depict the concentrations shown on the label. Manufacturers commonly include a greater amount of bacteria in their products than stated on the product label. This practice ensures that the recommended application rate of the inoculant is achieved. Conversely, improper storage and shipping conditions of inoculants may reduce the numbers of viable organisms; therefore, the inoculant will need to be applied at a higher rate to achieve the desired number of organisms. All of the treatments were dissolved in $200 \mathrm{~mL}$ of water and sprayed onto the forage mass under constant mixing, with the exception of SG, which was a granular formulation sprinkled onto the forage mass by hand during mixing. Samples of each treated forage pile were collected immediately after treatment but before ensiling. Representative portions of these samples were enumerated for yeasts and molds, as described later, and the remaining forage was frozen for chemical analysis. Within 5 min of treatment, forage for each treatment was packed in triplicate laboratory silos (20-L capacity, $92.7 \times 38.8 \mathrm{~cm}, \mathrm{~h} \times \mathrm{d})$ to achieve a final packing density of approximately 199 $\mathrm{kg}$ of $\mathrm{DM} / \mathrm{m}^{3}$. Silo covers were equipped with o-ring seals to prevent exposure to air while forage was ensiling. Whole plant corn was allowed to ensile for $122 \mathrm{~d}$ at ambient temperature $\left(20\right.$ to $\left.27^{\circ} \mathrm{C}\right)$ in a closed barn.

\section{Ensiling Procedure for Year 2}

The same cultivar of whole plant corn was harvested at one-half milk line and $32.8 \% \mathrm{DM}$ and handled as described in yr 1 . The following treatments were applied to each pile of fresh forage: 1) untreated (U), 2) L. buchneri 40788 applied at $4 \times 10^{5} \mathrm{cfu} / \mathrm{g}$ (LLB4), 3) L. buchneri $11 \mathrm{~A} 44$ applied at $1 \times 10^{5} \mathrm{cfu} / \mathrm{g}(\mathrm{PLB})$, 4) $L$. buchneri 11A44 applied at $4 \times 10^{5} \mathrm{cfu} / \mathrm{g}$ (PLB4), and 5) Biomax 5 applied at $1 \times 10^{5} \mathrm{cfu} / \mathrm{g}$ (B5). All treatments were applied at their commercial application rates except for PLB4. This treatment was used to compare the 2 strains of L. buchneri (40788 and 11A44) when applied 
at similar application rates. All of the treatments were dissolved in $200 \mathrm{~mL}$ of water and sprayed onto the forage mass under constant mixing. Sampling of forage and packing was as previously described except for packing density, which was approximately $231 \mathrm{~kg}$ of $\mathrm{DM} / \mathrm{m}^{3}$. Whole plant corn was allowed to ensile for 108 $\mathrm{d}$ at ambient temperature $\left(20\right.$ to $\left.27^{\circ} \mathrm{C}\right)$ in a closed barn.

\section{Chemical Analyses (Both Studies)}

The DM content of freshly treated samples on $d 0$ was determined by drying duplicate samples in a forced-air oven at $60^{\circ} \mathrm{C}$ for $48 \mathrm{~h}$. Water extracts were also prepared on fresh samples by adding $25 \mathrm{~g}$ of fresh forage to 225 $\mathrm{mL}$ of 25\% Ringer's solution (Oxoid BR52, Unipath, Basingstoke, UK) and homogenizing for $1 \mathrm{~min}$. The $\mathrm{pH}$ of the water extract was measured and a portion of it was filtered through Whatman 54 filter paper (Clifton, $\mathrm{NJ}$ ) and acidified with $50 \% \mathrm{H}_{2} \mathrm{SO}_{4}$ and frozen before analysis for ammonia-N (Weatherburn, 1967) using a phenol-hypochlorite method. The water-soluble carbohydrate (WSC) content of forages and silages was determined using a colorimetric method described by Nelson (1944).

After ensiling, DM recovery was calculated based on the initial weight of forage DM placed in the silos and the amount of silage DM removed after ensiling. Silages were processed and analyzed as described earlier. In addition, the water extracts were analyzed for lactic acid (kit 826-UV, Sigma-Aldrich, St. Louis, MO) and for ethanol (Sigma procedure no. 332-UV). For the analysis of D-lactic acid, L-lactic dehydrogenase was replaced with similar amounts of D-lactic dehydrogenase (Sigma L-9636). L-Lactic acid (Sigma L-2250) and Dlactic acid (Sigma L-1000) were used as standards for their respective assays. Total lactic acid is reported as the sum of D- and L-lactic acid. Acetic, propionic, and butyric acid concentrations were determined using a 5890 gas chromatograph (Hewlett Packard, Avondale, PA) with a 530- $\mu \mathrm{m}$ Carbowax $20 \mathrm{M}$ column and flameionization detector. The chromatograph oven was programmed as follows: $70^{\circ} \mathrm{C}$ for $1 \mathrm{~min}, 5^{\circ} \mathrm{C}$ increase/min to $100^{\circ} \mathrm{C}, 45^{\circ} \mathrm{C}$ increase $/ \mathrm{min}$ to $170^{\circ} \mathrm{C}$, and a final holding time of $5 \mathrm{~min}$.

The remaining water extract was filtered through a double layer of cheesecloth and enumerated for yeasts and molds by pour plating in malt extract agar (Oxoid CM59) that had been acidified with $85 \%$ lactic acid at a rate of $0.5 \%$ (vol/vol). Plates were incubated in a $32{ }^{\circ} \mathrm{C}$ oven for $2 \mathrm{~d}$ and counted for numbers of viable yeast and mold colonies.

Aerobic stability was determined by returning $3 \mathrm{~kg}$ of silage to its respective silo and exposing it to air at 22 to $25^{\circ} \mathrm{C}$. A thermocouple wire was placed in the geometric center of the forage mass. The wire was attached to a data logger (model number CR10X, Campbell Scientific, Inc., Logan, UT) that recorded the temperature every $10 \mathrm{~min}$ and averaged these values every $2 \mathrm{~h}$. Each silo was covered with a double layer of sterile cheesecloth to avoid contamination and drying out of the forage, yet allowing air to infiltrate the forage mass. Aerobic stability was defined as the number of hours that silage was exposed to air before a $2^{\circ} \mathrm{C}$ increase in temperature above ambient temperature.

Dried samples were ground with a UDY Cyclone Sample mill (UDY Corp., Fort Collins, CO) through a 1-mm screen. Samples were analyzed for NDF using sulfite and amylase (Van Soest et al., 1991) and ADF (Robertson and Van Soest, 1981) using an Ankom ${ }^{200}$ Fiber Analyzer (Ankom Technology, Fairport, NY). Crude protein was determined by total combustion of the sample (Leco CNS 2000 Analyzer, St. Joseph, MI) and multiplying total $\mathrm{N}$ by 6.25 .

\section{Statistical Analyses}

Microbial data were converted to $\log _{10}$ and presented on a fresh weight basis. Chemical data were presented on a DM basis. In each year, the experiment was a completely randomized design and data were analyzed using the GLM procedure (SAS Institute, 1998). Means separation was performed using Tukey's test (Snedecor and Cochran, 1980) with an $\alpha$ level of $P<0.05$ being deemed as significant.

\section{RESULTS}

\section{Year 1}

The chemical composition of freshly chopped corn in yr 1 is shown in Table 1 and was within expected ranges based on previous studies (Ranjit and Kung, 2000; Ranjit et al., 2002). The numbers of yeasts and molds for untreated forage were 6.57 and $5.90 \mathrm{log} \mathrm{cfu} / \mathrm{g}$, respectively (data not shown).

Chemical composition and DM recovery of corn silage after $122 \mathrm{~d}$ of ensiling is shown in Table 2. The DM content of the silages ranged from 25.5 to $27.9 \%$ and although there were differences among treatments, these differences were relatively small. The NDF, ADF, and ammonia- $\mathrm{N}$ contents were similar among all treatments. Microbial inoculation and chemical additives did not affect the concentration of CP compared with untreated silage. Treatment with SB and PSE produced silages with markedly greater concentrations of residual WSC (>8.50\%) compared with all other treatments (between 2.37 and $3.03 \%$ ). Dry matter recovery among the microbial inoculants was similar. Although numerically greater, DM recovery of microbial inoculants was 
Table 1. Chemical composition of fresh whole plant corn before ensiling in yr 1 (\% DM basis or as stated). ${ }^{1}$

\begin{tabular}{|c|c|c|c|c|c|c|c|c|}
\hline \multirow[b]{2}{*}{ Item } & \multicolumn{8}{|c|}{ Silage treatment ${ }^{2}$} \\
\hline & $\mathrm{U}$ & LLB4 & PLB & B5 & SG & $\mathrm{Ki}-112$ & SB & PSE \\
\hline $\mathrm{pH}$ & 5.19 & 4.83 & 5.07 & 4.78 & 5.02 & 5.11 & 5.10 & 5.00 \\
\hline $\mathrm{DM}, \%$ & 27.1 & 28.8 & 29.2 & 29.2 & 30.0 & 28.5 & 29.4 & 29.3 \\
\hline NDF & 40.3 & 39.3 & 39.2 & 41.2 & 42.7 & 41.2 & 41.0 & 40.9 \\
\hline $\mathrm{ADF}$ & 22.0 & 21.3 & 21.1 & 23.0 & 23.8 & 22.6 & 23.3 & 21.7 \\
\hline $\mathrm{CP}$ & 8.81 & 8.27 & 8.26 & 9.23 & 8.48 & 8.57 & 9.30 & 9.35 \\
\hline $\mathrm{NH}_{3}-\mathrm{N}, \mathrm{g} / \mathrm{kg}$ of $\mathrm{N}$ & 0.298 & 0.317 & 0.280 & 0.264 & 0.332 & 0.357 & 0.289 & 0.234 \\
\hline $\mathrm{WSC}^{3}$ & 16.0 & 15.8 & 14.5 & 14.8 & 13.8 & 16.9 & 14.3 & 14.3 \\
\hline
\end{tabular}

\footnotetext{
${ }^{1}$ Treatments contained one replicate, therefore statistical analyses was not conducted.

${ }^{2} \mathrm{U}=$ Untreated corn silage; LLB4 = corn silage treated with Lactobacillus buchneri 40788 at $4 \times 10^{5} \mathrm{cfu} /$ $\mathrm{g}$ of fresh forage; PLB = corn silage treated with L. buchneri $11 \mathrm{~A} 44$ at $1 \times 10^{5} \mathrm{cfu} / \mathrm{g}$; B5 = corn silage treated with Biomax 5 at $1 \times 10^{5} \mathrm{cfu} / \mathrm{g}$; SG = corn silage treated with sodium metabisulfite at $0.05 \%$; Ki-112= corn silage treated with a buffered propionic acid additive at $0.1 \% ; \mathrm{SB}=$ corn silage treated with sodium benzoate at $0.1 \%$; PSE $=$ corn silage treated with a mixture containing $50 \%$ potassium sorbate and $50 \%$ EDTA at $0.1 \%$.

${ }^{3} \mathrm{WSC}=$ Water-soluble carbohydrates.
}

not statistically greater than the DM recovery of untreated silage. Treatment with SB and PSE improved DM recovery (>99\% each) relative to U $(93 \%)$.

Fermentation products and numbers of yeasts from silages in yr 1 are shown in Table 3. Regardless of treatment, microbial inoculation had no effect on the final $\mathrm{pH}$ of silage when compared with untreated silage. Although no differences were detected for $\mathrm{pH}$ among the chemical additives SB- (3.61) and SG- (3.59) treated silages had a higher $\mathrm{pH}$ than did U-treated silages (3.44). Microbial (average of 7.74\%) and chemical (average of $7.70 \%$ ) additives had no effect on the concentration of lactic acid when compared with untreated silage, with the exception that SB lowered the concentration of lactic acid $(7.35 \%)$ compared with U (8.21\%). Silage treated with LLB4 had the highest concentration of acetic acid (2.83\%) among all of the treatments. Al- though the concentration of acetic acid was numerically higher in silage treated with PLB (2.47\%) compared with $\mathrm{U}(2.19 \%)$, the difference was not statistically significant. No differences were detected in the concentrations of acetic acid among the chemical additives but silage treated with SB had a lower concentration of this acid $(1.86 \%)$ than U. Inoculation with the 2 strains of L. buchneri resulted in silages that had lower lactate:acetate ratios (average of 2.93) than untreated silage (3.76) and silage treated with LLB4 (2.73) had a lower ratio than silage treated with PLB (3.12). The only treatment to have an appreciable concentration of propionic acid was $\mathrm{Ki}-112(0.37 \%)$. When compared with $\mathrm{U}$, the concentration of ethanol was markedly lower only in silages treated with SB and PSE (2.76 vs. 0.74 and $0.56 \%$, respectively). Lactobacillus buchneri 40788 was the only microbial inoculant that reduced

Table 2. The chemical composition of corn silage after $122 \mathrm{~d}$ of ensiling in yr 1 (\% DM basis or as stated).

\begin{tabular}{lccccccccc}
\hline & \multicolumn{7}{c}{ Silage treatment $^{1}$} \\
\cline { 2 - 9 } Item & $\mathrm{U}$ & LLB4 & PLB & B5 & SG & Ki-112 & SB & PSE & SE \\
\hline $\mathrm{DM}, \%$ & $25.5^{\mathrm{c}}$ & $26.2^{\mathrm{c}}$ & $26.8^{\mathrm{bc}}$ & $25.8^{\mathrm{c}}$ & $26.1^{\mathrm{c}}$ & $26.0^{\mathrm{c}}$ & $28.7^{\mathrm{a}}$ & $27.9^{\mathrm{ab}}$ & 0.34 \\
$\mathrm{NDF}$ & 43.6 & 41.1 & 42.6 & 44.5 & 43.2 & 45.2 & 41.0 & 39.0 & 1.4 \\
$\mathrm{ADF}$ & 26.0 & 23.1 & 24.3 & 25.9 & 25.1 & 26.3 & 22.3 & 22.1 & 0.9 \\
$\mathrm{CP}$ & $10.6^{\mathrm{abc}}$ & $11.0^{\mathrm{a}}$ & $9.80^{\mathrm{bc}}$ & $11.1^{\mathrm{a}}$ & $11.1^{\mathrm{a}}$ & $10.8^{\mathrm{a}}$ & $10.8^{\mathrm{ab}}$ & $9.73^{\mathrm{c}}$ & 0.2 \\
$\mathrm{NH}$-N, $^{2}$ g/kg of N & 0.598 & 0.535 & 0.600 & 0.539 & 0.576 & 0.588 & 0.562 & 0.573 & 0.022 \\
$\mathrm{WSC}^{2}$ & $2.70^{\mathrm{a}}$ & $2.37^{\mathrm{a}}$ & $3.03^{\mathrm{a}}$ & $2.67^{\mathrm{a}}$ & $2.57^{\mathrm{a}}$ & $2.77^{\mathrm{a}}$ & $9.67^{\mathrm{b}}$ & $8.90^{\mathrm{b}}$ & 0.35 \\
DMR $^{3}$ & $93.0^{\mathrm{b}}$ & $96.1^{\mathrm{ab}}$ & $98.0^{\mathrm{ab}}$ & $94.3^{\mathrm{b}}$ & $95.9^{\mathrm{ab}}$ & $95.0^{\mathrm{ab}}$ & $>99.0^{\mathrm{a}}$ & $>99.0^{\mathrm{a}}$ & 1.1 \\
\hline
\end{tabular}

\footnotetext{
a,b,c Means within rows with unlike superscripts differ $(P<0.05)$.

${ }^{1} \mathrm{U}=$ Untreated corn silage; LLB4 = corn silage treated with Lactobacillus buchneri 40788 at $4 \times 10^{5} \mathrm{cfu} /$ $\mathrm{g}$ of fresh forage; $\mathrm{PLB}=$ corn silage treated with L. buchneri $11 \mathrm{~A} 44$ at $1 \times 10^{5} \mathrm{cfu} / \mathrm{g}$; B5 = corn silage treated with Biomax 5 at $1 \times 10^{5} \mathrm{cfu} / \mathrm{g}$; SG = corn silage treated with sodium metabisulfite at $0.05 \%$; Ki-112= corn silage treated with a buffered propionic acid additive at $0.1 \% ; \mathrm{SB}=$ corn silage treated with sodium benzoate at $0.1 \%$; PSE $=$ corn silage treated with a mixture containing $50 \%$ potassium sorbate and 50\% EDTA at $0.1 \%$.

${ }^{2} \mathrm{WSC}=$ Water-soluble carbohydrates.

${ }^{3} \mathrm{DMR}=$ Dry matter recovery.
} 
Table 3. Fermentation end products and number of yeasts in corn silage after $122 \mathrm{~d}$ of ensiling in yr 1 ( $\%$ DM basis or as stated).

\begin{tabular}{llllllllll}
\hline & \multicolumn{7}{c}{ Silage treatment $1^{1}$} \\
\cline { 2 - 9 } Item & $\mathrm{U}$ & LLB4 & PLB & B5 & SG & Ki-112 & SB & PSE & SE \\
\hline pH & $3.44^{\mathrm{c}}$ & $3.50^{\mathrm{bc}}$ & $3.52^{\mathrm{abc}}$ & $3.50^{\mathrm{abc}}$ & $3.59^{\mathrm{ab}}$ & $3.51^{\mathrm{abc}}$ & $3.61^{\mathrm{a}}$ & $3.54^{\mathrm{abc}}$ & 0.02 \\
Lactic acid & $8.21^{\mathrm{a}}$ & $7.73^{\mathrm{ab}}$ & $7.70^{\mathrm{ab}}$ & $7.80^{\mathrm{ab}}$ & $7.69^{\mathrm{ab}}$ & $8.08^{\mathrm{ab}}$ & $7.35^{\mathrm{b}}$ & $7.65^{\mathrm{ab}}$ & 0.17 \\
Acetic acid & $2.19^{\mathrm{bc}}$ & $2.83^{\mathrm{a}}$ & $2.47^{\mathrm{b}}$ & $2.13^{\mathrm{cd}}$ & $2.08^{\mathrm{cd}}$ & $1.99^{\mathrm{cd}}$ & $1.86^{\mathrm{d}}$ & $2.02^{\mathrm{cd}}$ & 0.06 \\
Lactate:acetate ratio & $3.76^{\mathrm{ab}}$ & $2.73^{\mathrm{d}}$ & $3.12^{\mathrm{c}}$ & $3.66^{\mathrm{b}}$ & $3.69^{\mathrm{ab}}$ & $4.05^{\mathrm{a}}$ & $3.94^{\mathrm{ab}}$ & $3.79^{\mathrm{ab}}$ & 0.07 \\
Propionic acid & $0.03^{\mathrm{b}}$ & $<0.01^{\mathrm{bc}}$ & $0.00^{\mathrm{c}}$ & $0.02^{\mathrm{bc}}$ & $0.00^{\mathrm{c}}$ & $0.37^{\mathrm{a}}$ & $0.01^{\mathrm{bc}}$ & $0.01^{\mathrm{bc}}$ & 0.01 \\
Ethanol & $2.76^{\mathrm{a}}$ & $3.09^{\mathrm{a}}$ & $3.40^{\mathrm{a}}$ & $3.39^{\mathrm{a}}$ & $3.71^{\mathrm{a}}$ & $3.63^{\mathrm{a}}$ & $0.74^{\mathrm{b}}$ & $0.56^{\mathrm{b}}$ & 0.20 \\
Yeasts, $\log _{10}$ cfu/g & & & & & & & & & \\
of fresh weight & $4.43^{\mathrm{a}}$ & $<2.00^{\mathrm{b}}$ & $3.70^{\mathrm{a}}$ & $4.82^{\mathrm{a}}$ & $4.61^{\mathrm{a}}$ & $4.25^{\mathrm{a}}$ & $3.47^{\mathrm{a}}$ & $2.96^{\mathrm{ab}}$ & 0.46 \\
\hline
\end{tabular}

a,b,c,d Means within rows with unlike superscripts differ $(P<0.05)$.

${ }^{1} \mathrm{U}=$ Untreated corn silage; LLB4 = corn silage treated with Lactobacillus buchneri 40788 at $4 \times 10^{5} \mathrm{cfu} /$ $\mathrm{g}$ of fresh forage; PLB = corn silage treated with L. buchneri $11 \mathrm{~A} 44$ at $1 \times 10^{5} \mathrm{cfu} / \mathrm{g}$; B5 = corn silage treated with Biomax 5 at $1 \times 10^{5} \mathrm{cfu} / \mathrm{g} ; \mathrm{SG}=$ corn silage treated with sodium metabisulfite at $0.05 \%$; Ki-112= corn silage treated with a buffered propionic acid additive at $0.1 \% ; \mathrm{SB}=$ corn silage treated with sodium benzoate at $0.1 \%$; PSE $=$ corn silage treated with a mixture containing $50 \%$ potassium sorbate and $50 \%$ EDTA at $0.1 \%$.

the numbers of yeasts in corn silage. The reduction in the numbers of yeasts by LLB4 was dramatic, as yeasts were nearly undetectable in this silage. Molds were not present in any of the treatments (data not shown).

The aerobic stability among treatments is shown in Figure 1. Aerobic stability of silage treated with LLB4 was $139 \mathrm{~h}$ and it was the only microbial inoculant to improve aerobic stability when compared with $\mathrm{U}$, which remained stable for only $39 \mathrm{~h}$. Of the chemical additives,

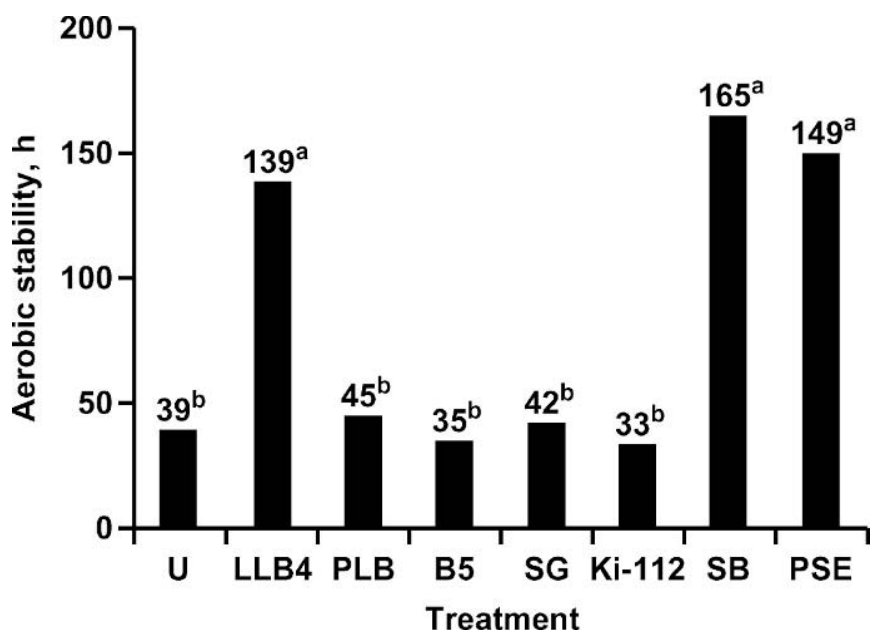

Figure 1. Effect of microbial inoculants and chemical additives on the aerobic stability of corn silage after $122 \mathrm{~d}$ of ensiling in yr 1 . $\mathrm{U}=$ untreated, LLB4 = Lactobacillus buchneri 40788 at $4 \times 10^{5} \mathrm{cfu} /$ $\mathrm{g}$ of fresh forage, PLB $=L$. buchneri $11 \mathrm{~A} 44$ at $1 \times 10^{5} \mathrm{cfu} / \mathrm{g}, \mathrm{B} 5=$ Biomax 5, L. plantarum PA-28 and K-270, at $1 \times 10^{5} \mathrm{cfu} / \mathrm{g}, \mathrm{SG}=$ SiloGuard II, sodium metabisulfite, applied at $0.05 \%$ of fresh forage weight, Ki-112 = Ultra Curb, buffered propionic acid, applied at $0.1 \%$, $\mathrm{SB}=$ sodium benzoate applied at $0.1 \%$, and $\mathrm{PSE}=$ potassium sorbate, $50 \%$ and EDTA, 50\% applied at $0.1 \%$. Bars with unlike letters differ $(P<0.05 ; \mathrm{SE}=31)$. silages treated with SB and PSE were stable for 165 and $149 \mathrm{~h}$, respectively (improved relative to $\mathrm{U}$ ), whereas SG and Ki-112 had no effect on aerobic stability.

\section{Year 2}

The chemical composition of fresh whole plant corn before ensiling in yr 2 is shown in Table 4. The initial $\mathrm{pH}$ of silage treated with LLB4 (5.45) was greater than $\mathrm{U}$ (5.33) but was similar to the other treatments and this difference has little biological significance. The DM content and concentrations of ammonia-N were similar among all treatments. The NDF and ADF contents of all treatments were similar to U. Untreated silage had the greatest concentration of CP (8.90 vs. $7.90 \%)$. Silages treated with PLB4 (11.7\%) and LLB4 (10.5\%) had lower concentrations of WSC compared with U (13.5\%).

The chemical composition of corn silage after $108 \mathrm{~d}$ of ensiling is shown in Table 5. No differences in DM, $\mathrm{NDF}, \mathrm{ADF}$, and ammonia-N percentage were observed among treatments. Silage treated with LLB4 had a lower concentration of $\mathrm{CP}$ compared with all treatments except PLB. Silages treated with PLB (1.92\%), PLB4 (1.55\%), and LLB4 (1.46\%) had lower concentrations of WSC than U (5.17\%). Dry matter recovery was not affected by treatment.

Fermentation products and numbers of yeasts from silages in yr 2 are shown in Table 6 . The $\mathrm{pH}$ of silage treated with PLB4 was greater than for all other treatments with the exception of silage treated with PLB. The concentration of lactic acid in silage treated with B5 (8.81\%) was the highest of all treatments. Silages treated with $L$. buchneri inoculants had lower concentrations of lactic acid $(6.75,7.12$, and $5.57 \%$ for LLB4, 
Table 4. Chemical composition (DM basis) of freshly chopped whole plant corn before ensiling in yr 2 (\% DM basis or as stated).

\begin{tabular}{lcccccl}
\hline & \multicolumn{5}{c}{ Silage treatment ${ }^{1}$} \\
\cline { 2 - 7 } Item & $\mathrm{U}$ & $\mathrm{PLB}$ & $\mathrm{PLB} 4$ & LLB4 & $\mathrm{B} 5$ & $\mathrm{SE}$ \\
\hline $\mathrm{pH}$ & $5.33^{\mathrm{b}}$ & $5.39^{\mathrm{ab}}$ & $5.39^{\mathrm{ab}}$ & $5.45^{\mathrm{a}}$ & $5.37^{\mathrm{ab}}$ & 0.02 \\
$\mathrm{DM}, \%$ & 32.2 & 32.7 & 32.9 & 33.8 & 32.4 & 0.5 \\
$\mathrm{NDF}$ & $38.2^{\mathrm{ab}}$ & $39.3^{\mathrm{ab}}$ & $40.8^{\mathrm{a}}$ & $36.4^{\mathrm{b}}$ & $37.6^{\mathrm{ab}}$ & 0.7 \\
$\mathrm{ADF}$ & $21.4^{\mathrm{ab}}$ & $21.2^{\mathrm{ab}}$ & $22.5^{\mathrm{a}}$ & $19.7^{\mathrm{ab}}$ & $19.1^{\mathrm{b}}$ & 0.7 \\
$\mathrm{CP}$ & $8.90^{\mathrm{a}}$ & $7.85^{\mathrm{b}}$ & $7.65^{\mathrm{b}}$ & $7.97^{\mathrm{b}}$ & $8.13^{\mathrm{b}}$ & 0.14 \\
$\mathrm{NH}$-N $^{2}, \mathrm{~g} / \mathrm{kg}$ of N & 0.219 & 0.236 & 0.259 & 0.248 & 0.241 & 0.017 \\
WSC $^{2}$ & $13.5^{\mathrm{a}}$ & $12.4^{\mathrm{ab}}$ & $11.7^{\mathrm{bc}}$ & $10.5^{\mathrm{c}}$ & $13.6^{\mathrm{a}}$ & 0.3 \\
\hline
\end{tabular}

a,b,c,d Means within rows with unlike superscripts differ $(P<0.05)$.

${ }^{1} \mathrm{U}=$ Untreated corn silage; PLB = corn silage treated with L. buchneri $11 \mathrm{~A} 44$ at $1 \times 10^{5} \mathrm{cfu} / \mathrm{g}$ of fresh forage; PLB4 = corn silage treated with $L$. buchneri $11 \mathrm{~A} 44$ at $4 \times 10^{5} \mathrm{cfu} / \mathrm{g} ;$ LLB4 $=$ corn silage treated with L. buchneri 40788 at $4 \times 10^{5} \mathrm{cfu} / \mathrm{g}$; B5 = corn silage treated with Biomax 5 at $1 \times 10^{5} \mathrm{cfu} / \mathrm{g}$.

${ }^{2} \mathrm{WSC}=$ Water-soluble carbohydrates.

PLB, and PLB4, respectively) compared with U (7.90\%), with PLB4-treated silage containing the lowest concentration of this acid. Silage treated with PLB4 (7.59\%) had the greatest concentration of acetic acid of all treatments. Silages treated with PLB (6.31\%) and LLB4 (6.29\%) had greater concentrations of acetic acid than in $\mathrm{U}(3.29 \%)$. The lactate:acetate ratio of silage treated with B5 (3.04) was greater than U (2.40), whereas inoculation with $L$. buchneri decreased this ratio $(1.13,0.74$, and 1.08 for PLB, PLB4, and LLB4, respectively) compared with $U$. The concentration of ethanol in silage treated with B5 $(1.75 \%)$ was greater than levels present in $\mathrm{U}(0.90 \%)$, whereas silages treated with PLB $(0.64 \%)$, PLB4 (0.62\%), and LLB4 (0.56\%) had lower concentrations of ethanol than U. Yeasts were not present in any of the silages except for those treated with B5 (4.95 $\log _{10} \mathrm{cfu} / \mathrm{g}$ of silage). Molds were undetectable in all treatments (data no shown). The aerobic stability of corn silage is shown in Figure 2. Silages treated with PLB, PLB4, and LLB4 were more aerobically stable than $\mathrm{U}(73 \mathrm{~h})$ and remained stable for $>210 \mathrm{~h}$. However, treating silage with B5 (52 h) made aerobic stability worse compared with U.

\section{DISCUSSION}

In general, silages appeared to be more challenged by yeasts in yr 1 than in yr 2 . The lower packing density in yr $1\left(199 \mathrm{~kg} / \mathrm{m}^{3}\right)$ compared with yr $2\left(231 \mathrm{~kg} / \mathrm{m}^{3}\right)$ may have prolonged the existence of the yeasts in silages made in yr 1. However, these silages were made in different years and normal year-to-year differences (growing season, maturity, etc.) may also have had a significant effect. The differences in packing density and plant maturity were not planned. In the first year, after ensiling, yeasts in silages ranged from 2.96 to 4.82 $\log _{10} \mathrm{cfu} / \mathrm{g}$ with the exception of nondetectable numbers in silages treated with LLB4. In contrast, in yr 2, numbers of yeasts were less than $2.00 \mathrm{log} \mathrm{cfu} / \mathrm{g}$ in all silages with the exception of silage treated with B5 (4.95 log

Table 5. Chemical composition of corn silage after $108 \mathrm{~d}$ of ensiling in yr 2 (\% DM basis or as stated).

\begin{tabular}{|c|c|c|c|c|c|c|}
\hline \multirow[b]{2}{*}{ Item } & \multicolumn{6}{|c|}{ Silage treatment ${ }^{1}$} \\
\hline & $\mathrm{U}$ & PLB & PLB4 & LLB4 & B5 & $\mathrm{SE}$ \\
\hline $\mathrm{DM}, \%$ & 30.2 & 29.8 & 30.0 & 30.6 & 29.7 & 0.2 \\
\hline NDF & 40.7 & 41.7 & 42.3 & 39.1 & 38.8 & 0.8 \\
\hline $\mathrm{ADF}$ & 21.8 & 24.4 & 23.8 & 25.6 & 25.9 & 0.9 \\
\hline $\mathrm{CP}$ & $9.56^{\mathrm{a}}$ & $9.02^{\mathrm{ab}}$ & $9.21^{\mathrm{a}}$ & $8.42^{\mathrm{b}}$ & $9.40^{\mathrm{a}}$ & 0.2 \\
\hline $\mathrm{NH}_{3}-\mathrm{N}, \mathrm{g} / \mathrm{kg}$ of $\mathrm{N}$ & 0.643 & 0.637 & 0.606 & 0.674 & 0.638 & 0.021 \\
\hline $\mathrm{WSC}^{2}$ & $5.17^{\mathrm{a}}$ & $1.92^{\mathrm{b}}$ & $1.55^{\mathrm{b}}$ & $1.46^{\mathrm{b}}$ & $4.88^{\mathrm{a}}$ & 0.13 \\
\hline $\mathrm{DMR}^{3}$ & 93.0 & 90.4 & 90.0 & 89.9 & 91.0 & 0.7 \\
\hline
\end{tabular}

a,b,c,d Means within rows with unlike superscripts differ $(P<0.05)$.

${ }^{1} \mathrm{U}=$ Untreated corn silage; PLB = corn silage treated with $L$. buchneri $11 \mathrm{~A} 44$ at $1 \times 10^{5} \mathrm{cfu} / \mathrm{g}$ of fresh forage; PLB4 = corn silage treated with L. buchneri $11 \mathrm{~A} 44$ at $4 \times 10^{5} \mathrm{cfu} / \mathrm{g}$; LLB4 = corn silage treated with L. buchneri 40788 at $4 \times 10^{5} \mathrm{cfu} / \mathrm{g}$; B5 = corn silage treated with Biomax 5 at $1 \times 10^{5} \mathrm{cfu} / \mathrm{g}$.

${ }^{2} \mathrm{WSC}=$ Water-soluble carbohydrates.

${ }^{3} \mathrm{DMR}=$ Dry matter recovery 
Table 6. Fermentation end products and number of yeasts in corn silage after $108 \mathrm{~d}$ of ensiling in yr $2(\%$ DM basis or as stated).

\begin{tabular}{|c|c|c|c|c|c|c|}
\hline \multirow[b]{2}{*}{ Item } & \multicolumn{6}{|c|}{ Silage treatment ${ }^{1}$} \\
\hline & $\mathrm{U}$ & PLB & PLB4 & LLB4 & B5 & $\mathrm{SE}$ \\
\hline $\mathrm{pH}$ & $3.50^{\mathrm{b}}$ & $3.56^{\mathrm{ab}}$ & $3.67^{\mathrm{a}}$ & $3.51^{\mathrm{b}}$ & $3.48^{\mathrm{b}}$ & 0.03 \\
\hline Lactic acid & $7.90^{\mathrm{b}}$ & $7.12^{\mathrm{c}}$ & $5.57^{\mathrm{d}}$ & $6.75^{\mathrm{c}}$ & $8.81^{\mathrm{a}}$ & 0.07 \\
\hline Acetic acid & $3.29^{\mathrm{c}}$ & $6.31^{\mathrm{b}}$ & $7.59^{\mathrm{a}}$ & $6.29^{\mathrm{b}}$ & $2.92^{\mathrm{c}}$ & 0.22 \\
\hline Lactate:acetate ratio & $2.40^{\mathrm{b}}$ & $1.13^{\mathrm{c}}$ & $0.74^{\mathrm{d}}$ & $1.08^{\mathrm{cd}}$ & $3.04^{\mathrm{a}}$ & 0.08 \\
\hline Ethanol & $0.90^{\mathrm{b}}$ & $0.64^{\mathrm{c}}$ & $0.62^{\mathrm{c}}$ & $0.56^{\mathrm{c}}$ & $1.75^{\mathrm{a}}$ & 0.04 \\
\hline Yeasts, log cfu/g of fresh weight & $<2.00^{\mathrm{b}}$ & $<2.00^{\mathrm{b}}$ & $<2.00^{\mathrm{b}}$ & $<2.00^{\mathrm{b}}$ & $4.95^{\mathrm{a}}$ & 0.29 \\
\hline
\end{tabular}

$\mathrm{cfu} / \mathrm{g})$. The concentration of ethanol in corn silages ranged from 2.76 to $3.71 \%$ in yr 1 , whereas they were lower (less than $1 \%$ with the exception of silages treated with B5 at $1.75 \%$ ) in yr 2. This finding was probably associated with the populations of yeasts in silages in each year; however, the maturity at harvest may also have played a significant role. Silage in yr 1 was more immature and it had a higher concentration of WSC compared with silage in yr 2 (15 vs. $12 \%)$. Wu-Tai et al. (2002) observed that corn silage treated with glucose (1.25 and $2.50 \%$ of fresh forage weight) at harvest had a higher concentration of ethanol after ensiling compared with untreated silage, and this effect was further enhanced by increasing amount of glucose.

Specifically in yr 1, corn silage inoculated with PLB (i.e., $1 \times 10^{5} \mathrm{cfu} / \mathrm{g}$ of L. buchneri $11 \mathrm{~A} 44$ ) did not contain

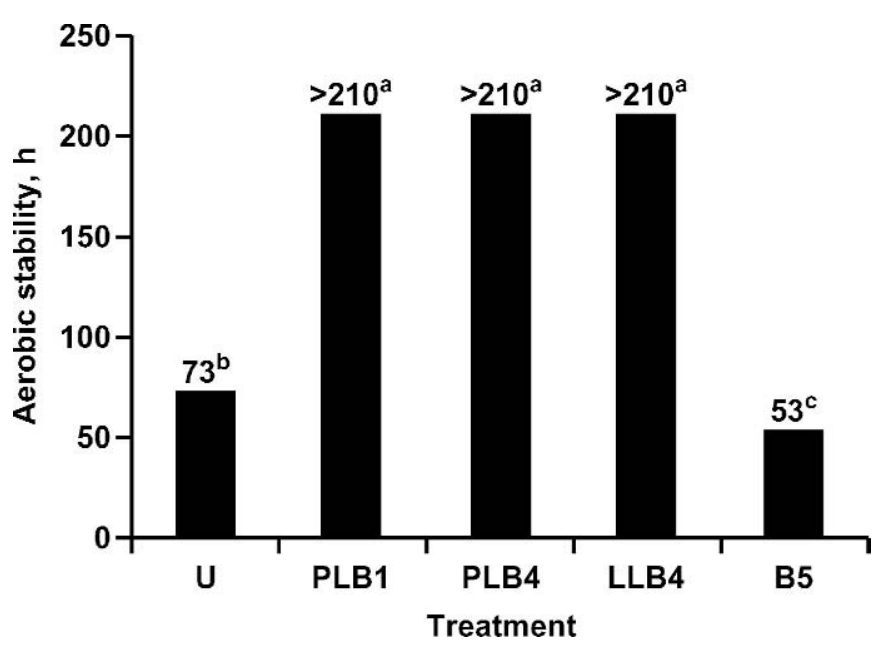

Figure 2. Effect of microbial inoculants on the aerobic stability of corn silage after $108 \mathrm{~d}$ of ensiling. $\mathrm{U}=$ untreated, PLB1 = Lactobacillus buchneri $11 \mathrm{~A} 44$ at $1 \times 10^{5} \mathrm{cfu} / \mathrm{g}$ of fresh forage, PLB $4=L$. buchneri $11 \mathrm{~A} 44$ at $4 \times 10^{5} \mathrm{cfu} / \mathrm{g}, \mathrm{LLB} 4=$ L. buchneri 40788 at $4 \times 10^{5} \mathrm{cfu} / \mathrm{g}$, B5 = Biomax 5, L. plantarum PA-28 and K-270, at $1 \times 10^{5} \mathrm{cfu} / \mathrm{g}$. Bars with unlike letters differ $(P<0.05 ; \mathrm{SE}=4)$. as much acetic acid as did silage treated with LLB4 (4 $\times 10^{5} \mathrm{cfu} / \mathrm{g}$ of $L$. buchneri 40788 ). In addition to this finding, silage treated with LLB4 but not PLB was more aerobically stable than untreated silage. In yr 2 , silages treated with PLB $\left(1 \times 10^{5} \mathrm{cfu} / \mathrm{g}\right.$ of $L$. buchneri 11A44) and LLB4 $\left(4 \times 10^{5} \mathrm{cfu} / \mathrm{g}\right.$ of L. buchneri 40788$)$ had similar concentrations of acetic acid, and both treatments were more aerobically stable than was untreated silage. Unlike treatment with LLB4, treating silage with PLB may have only been ineffective in yr 1 because its application rate may not have been adequate to compete against detrimental organisms in more poorly packed silage. Silage treated with the higher dose of PLB4 had more acetic acid than did silage treated with the same number of $L$. buchneri 40788. In previous studies from our laboratory, we reported only small improvements in aerobic stability of corn silage when $L$. buchneri 40788 was applied at rates of less than $2.5 \times 10^{5} \mathrm{cfu} / \mathrm{g}$ (Ranjit and Kung, 2000; Ranjit et al., 2002). In the current study, regardless of strain or rate of inoculation, all silages in yr 2 that were treated with $L$. buchneri were more stable than untreated silage but we did not determine if there were differences among the inoculated silages as we discontinued the monitoring of temperatures after $210 \mathrm{~h}$ of aerobic exposure. Muck (2004) evaluated 3 strains of $L$. buchneri, 2 of them being LLB4 and PLB. In his studies, all strains of L. buchneri improved the aerobic stability of corn silage but LLB4 was the most effective. Another strain of L. buchneri, NRRL B-1837, has been shown to improve the aerobic stability of corn silage (Weinberg et al., 2002). In contrast to yr 1, treatment with $L$. buchneri in yr 2 decreased the concentrations of WSC. Similar results have been observed in some studies (Kung and Ranjit, 2001; Kung et al., 2003) but not in others (Driehuis et al., 2001; Taylor et al., 2002). It has been established that $L$. buchneri uses glucose as a substrate when it is available (Oude Elferink et al., 2001); however, factors that may trigger the metabolism of glucose by L. buch- 
neri in silage are unknown. One criticism of treating forages with $L$. buchneri has been the presumption that small amounts of $\mathrm{CO}_{2}$ are produced when lactic acid is metabolized into acetic acid and other end products (Oude Elferink et al., 2001), and this could result in increased DM losses in treated silages. Lower DM recovery after ensiling has been reported in some (Driehuis et al., 1999, 2001) but not all (Taylor et al., 2002; Ranjit et al., 2002) silages treated with L. buchneri. Inoculation with $L$. buchneri did not affect DM recovery of corn silage in either year of this study.

Silage treated with B5 (which contained 2 strains of $L$. plantarum) did not improve fermentation, DM recovery, or aerobic stability in yr 1 . In yr 2, silage treated with B5 had the greatest concentrations of lactic acid and the highest ratio of lactate:acetate, indicative of a more homolactic acid type of fermentation. However, this silage also had the highest concentration of ethanol, the greatest number of yeasts, and poorest aerobic stability of all silages. This finding was not surprising, as homolactic acid inoculants have sometimes decreased aerobic stability probably because of a lack of production of antifungal acids (Weinberg et al., 1993; Muck and Kung, 1997). Muck (2004) also evaluated this silage inoculant in 3 successive years and B5 improved aerobic stability in only 1 of $3 \mathrm{yr}$.

Various chemical additives with antifungal properties have been used together to enhance the aerobic stability of silages. Buffered propionic acid is the main active ingredient in many commercial silage preservatives but sorbate or benzoate is also commonly found as a minor component. Undissociated propionic acid has strong antifungal properties, and the fraction of propionic acid that is undissociated is dependent on $\mathrm{pH}$ (Lambert and Stratford, 1999). At the $\mathrm{pH}$ of a standing crop (about 6), only about $1 \%$ of the acid is in the undissociated form, whereas, at a $\mathrm{pH}$ of 4.8 , about $50 \%$ of the acid is undissociated. The undissociated acid functions by staying active on the surface of microorganisms and by competing with amino acids for space on active sites of enzymes and by altering the cell permeability of microbes (Buxton et al., 2003). We combined potassium sorbate with EDTA because Razavi-Rohani and Griffiths (1999) reported that the latter improved the antimycotic effect of sorbic and propionic acids in pure culture. Chelators such as EDTA have been shown to enhance the weak acid effect on yeasts via the binding of zinc, which may interfere with normal cell wall metabolism (Brul et al., 1997). The buffered propionic acid additive tested in the present study predictably increased the concentration of propionic acid but failed to prevent the accumulation of yeasts and improve stability, probably because of its low application rate $(0.1 \%$ of fresh forage weight). In previous studies, we found that, as expected, the effectiveness of propionic acidbased additives increased with higher application rates (Kung et al., 1998, 2000). The dose used in the current study might have been insufficient to inhibit the growth of yeasts. Treating silages with the chemical-based additives, SB and PSE, improved DM recovery and resulted in silages with the highest concentrations of residual WSC, suggesting partial inhibition of fermentation. Alli et al. (1985) reported that corn silage treated with $0.09 \%$ sorbic acid or potassium sorbate improved aerobic stability, and they suggested that this finding was caused by inhibition of yeasts and not lactic acid bacteria. Our data support this contention because the concentrations of lactic acid were not markedly affected by SB and PSE, whereas the concentrations of ethanol were lower compared with that of untreated silage. In the current study, of the chemical additives, only sodium benzoate and potassium sorbate + EDTA improved the aerobic stability of silages.

The additive containing sodium metabisulfite and amylase had no effect on silage fermentation, DM recovery, or aerobic stability in our study. During ensiling, sodium metabisulfite is degraded into sulfur dioxide, which is highly antifungal. In addition, this compound is a strong reducing agent that can consume large quantities of oxygen during ensiling; thereby reducing the time that the fresh forage is under aerobic stress (McDonald et al., 1991). Alli and Baker (1982) reported that addition of sodium metabisulfite $(0.5 \%)$ inhibited microbial activity and increased the concentration of WSC in corn silage. Furthermore, it was concluded by Buxton et al. (2003) that treating silages with sodium metabisulfite increased the $\mathrm{pH}$ and lowered the fermentation acids. These findings were indicative of microbial inhibition, specifically that of heterofermentative bacteria. Even though the concentration of WSC was not affected in this study, treating silage with sodium metabisulfite increased the $\mathrm{pH}$ and numerically decreased the fermentation acids, presumably through microbial inhibition. In agreement with our findings, treatment with sodium metabisulfite has been reported by others to be ineffective at improving aerobic stability in corn silage (Soderlund et al., 1983; Bolsen et al., 1985).

\section{CONCLUSIONS}

Addition of a microbial inoculant containing several strains of $L$. plantarum improved the ratio of lactic:acetic acid in 1 of $2 \mathrm{yr}$ but never affected the DM recovery or improved the aerobic stability of corn silage. Of the chemical additives, only treatments of sodium benzoate and potassium sorbate + EDTA (but not a buffered propionic acid additive, nor an additive containing sodium metabisulfite) improved the aerobic stability and DM 
recovery of silage. Lactobacillus buchneri $11 \mathrm{~A} 44$, added at its commercial rate of $1 \times 10^{5} \mathrm{cfu} / \mathrm{g}$, increased the concentration of acetic acid in silage and aerobic stability in 1 of $2 \mathrm{yr}$. A higher dose of $4 \times 10^{5} \mathrm{cfu} / \mathrm{g}$ further stimulated the production of acetic acid and improved the aerobic stability of corn silage. Lactobacillus buchneri 40788, applied at its commercial rate of $4 \times 10^{5}$ $\mathrm{cfu} / \mathrm{g}$, increased the concentrations of acetic acid and improved the aerobic stability of corn silage in both years that it was tested. Dry matter recovery was unaffected by either strain of L. buchneri.

\section{ACKNOWLEDGMENTS}

The authors thank Caroline Golt, Jill Lynch, Jill Ladd, Jeanne Neylon, Tisha Ebling, Missy Reddish, and Brian Stockinger for analytical assistance. We also thank the farm crew of the University of Delaware for care and harvesting of the corn silage. This study was partially funded by Lallemand Animal Nutrition, Milwaukee, WI.

\section{REFERENCES}

Adesogan, A. T., M. B. Salawu, A. B. Ross, D. R. Davies, and A. E. Brooks. 2002. Effect of Lactobacillus buchneri, Lactobacillus fermentum, Leuconostoc mesenteroides inoculants, or a chemical additive on the fermentation, aerobic stability, and nutritive value of crimped wheat grains. J. Dairy Sci. 86:1789-1796.

Alli, I., and B. E. Baker. 1982. Effects of additives on lactic acid production and water-soluble carbohydrates in chopped corn and alfalfa. J. Dairy Sci. 65:1472-1478.

Alli, I., S. Pabari, R. Fairbairn, and B. E. Baker. 1985. The effects of sorbates on the ensilage of chopped whole-plant maize and lucerne. J. Sci. Food Agric. 36:63-70.

Bolsen, K., H. Ilg, R. Smith, J. Hoover, and D. Axe. 1985. Droughtstressed, irrigated, and additive-treated corn silages for growing cattle. Pages 60-65 in Proceedings of Cattlemen's Day 1985. Agricultural Experiment Station. Kansas State University, Manhattan.

Brul, S., M. Stratford, J. M. Van der Vaart, S. K. Diebandhoesing, S. K. Steels, M. Klis, and C. T. Verrips. 1997. The antifungal action of 1,10-o-phenantholine and EDTA is mediated through zinc chelation and involves cell wall construction. Food Technol. Biotechnol. 35:267-274.

Buxton, D. R., R. E. Muck, and J. H. Harrison. 2003. Silage Science and Technology. American Society of Agronomy, Inc., Crop Science Society of America, Inc., Soil Science Society of America, Inc. Publications, Madison, WI.

Driehuis, F., S. J. W. H. Oude Elferink, and S. F. Spolestra. 1999 Anaerobic lactic acid degradation during ensilage of whole crop maize inoculated with Lactobacillus buchneri inhibits yeast growth and improves aerobic stability. J. Appl. Microbiol. 87:583-594.

Driehuis, F., S. J. W. H. Oude Elferink, and P. G. Van Wikselaar. 2001. Fermentation characteristics and aerobic stability of grass silage inoculated with Lactobacillus buchneri, with or without homofermentative lactic acid bacteria. Grass Forage Sci. 56:330-343.

Hoffman, P. C., and S. M. Ocker. 1997. Quantification of milk yield losses associated with feeding aerobically unstable high moisture corn. J. Dairy Sci. 80(Suppl. 1):234. (Abstr.)

Kung, L., Jr., C. C. Taylor, M. P. Lynch, and J. M. Neylon. 2003. The effect of treating alfalfa with Lactobacillus buchneri 40788 on silage fermentation, aerobic stability, and nutritive value for lactating dairy cows. J. Dairy Sci. 86:336-343.

Kung, L., Jr., and N. K. Ranjit. 2001. The effect of Lactobacillus buchneri and other additives on the fermentation and aerobic stability of barley silage. J. Dairy Sci. 84:1149-1155.

Kung, L., Jr., A. C. Sheperd, A. M. Smagala, K. M. Endres, C. A. Bessett, N. K. Ranjit, and J. L. Glancey. 1998. The effect of preservatives based on propionic acid on the fermentation and aerobic stability of corn silage and a total mixed ration. J. Dairy Sci. 81:1322-1330.

Kung, L., Jr., J. R. Robinson, N. K. Ranjit, J. H. Chen, C. M. Golt, and J. D. Pesek. 2000. Microbial populations, fermentation endproducts, and aerobic stability of corn silage treated with ammonia or a propionic acid-based preservative. J. Dairy Sci. 83:1479-1486.

Lambert, R. J., and M. Stratford. 1999. Weak-acid preservatives: Modeling microbial inhibition and response. J. Appl. Microbiol. 86:157-164

Lingvall, P., and P. Lattemae. 1999. Influence of hexamine and sodium nitrite in combination with sodium benzoate and sodium propionate on fermentation and hygienic quality of wilted and long cut grass silage. J. Sci. Food Agric. 79:257-264.

McDonald, P., N. Henderson, and S. J. E. Heron. 1991. The Biochemistry of Silage. 2nd ed. Chalcombe Publications, Bucks, UK.

Muck, R. E. 1996. A lactic acid bacteria strain to improve aerobics stability of silages. Pages $42-43$ in U.S. Dairy Forage Res. Center 1996 Res. Summaries, Madison, WI.

Muck, R. E. 2004. Effects of corn silage inoculants on aerobic stability. Trans. ASAE 47:1011-1016.

Muck, R. E., and L. Kung, Jr. 1997. Effects of silage additives ensiling. Pages 187-199 in Silage: Field to Feedbunk. NRAES-99. NRAES, Ithaca, NY.

Nelson, N. 1944. A photometric adaptation of the Smogyi method for the determination of glucose. J. Biol. Chem. 153:375-380.

Oude Elferink, S. J. W. H., J. Krooneman, J. C. Gottschal, S. F. Spoelstra, F. Faber, and F. Driehuis. 2001. Anaerobic conversion of lactic acid to acetic acid and 1,2-propanediol by Lactobacillus buchneri. Appl. Environ. Microbiol. 67:125-132.

Ranjit, N. K., and L. Kung, Jr. 2000. The effect of Lactobacillus buchneri, Lactobacillus plantarum, or a chemical preservative on the fermentation and aerobic stability of corn silage. J. Dairy Sci. 83:526-535.

Ranjit, N. K., C. C. Taylor, and L. Kung, Jr. 2002. Effect of Lactobacillus buchneri 40788 on the fermentation, aerobic stability and nutritive value of maize silage. Grass Forage Sci. 57:73-81.

Razavi-Rohani, S. M., and M. W. Griffiths. 1999. Antifungal effects of sorbic acid and propionic acid at different $\mathrm{pH}$ and $\mathrm{NaCl}$ conditions. J. Food Safety 19:109-120.

Robertson, J. B., and P. J. Van Soest. 1981. The detergent system of analysis and its application to human foods. Pages 123-158 in The Analysis of Dietary Fiber in Food. W. P. T. James and O. Theander, ed. Marcel Dekker Inc., New York, NY.

SAS Institute. 1998. SAS User's Guide. Statistics, Version 7 ed. 1998. SAS Inst., Inc., Cary, NC.

Snedecor, G. W., and W. G. Cochran. 1980. Statistical Methods. 6th ed. Iowa State Univ. Press, Ames, IA.

Soderlund, S., K. Bolsen, H. Ilg, and J. Hoover. 1983. Pages 53-57 in Proceedings of Cattlemen's Day 1983. Agricultural Experiment Station. Kansas State University, Manhattan, KS.

Taylor, C. C., N. J. Ranjit, J. A. Mills, J. M. Neylon, and L. Kung, Jr. 2002. The effect of treating whole-plant barley with Lactobacillus buchneri 40788 on silage fermentation, aerobic stability, and nutritive value for dairy cows. J. Dairy Sci. 85:1793-1800.

Van Soest, P. J., J. B. Robertson, and B. A. Lewis. 1991. Methods for dietary fiber, neutral detergent fiber, and nonstarch polysaccharides in relation to animal nutrition. J. Dairy Sci. 74:35833597.

Weatherburn, M. W. 1967. Phenol-hypochlorite reaction for determinations of ammonia. Anal. Chem. 39:971-974.

Weinberg, Z. G., G. Ashbell, Y. Hen, and A. Azrieli. 1993. The effect of applying lactic acid bacteria on the aerobic stability of silages. J. Appl. Bacteriol. 75:512-518. 
Weinberg, Z. G., G. Ashbell, Y. Hen, A. Azreili, G. Szakacs, and I. Filya. 2002. Ensiling whole-crop wheat and corn in large containers with Lactobacillus plantarum and Lactobacillus buchneri. J. Ind. Micro. Biotechnol. 28:7-11.

Whitlock, L. A., T. J. Wistuba, M. K. Seifers, R. V. Pope, and K. K. Bolsen. 2000. Effect of level of surface-spoiled silage on the nutritive value of corn silage diets. J. Dairy Sci. 83(Suppl. 1):110. (Abstr.)
Woolford, M. K. 1975. Microbiological screening of food preservatives, cold sterilants and specific antimicrobial agents as potential silage additives. J. Sci. Food Agric. 26:229-237.

Woolford, M. K. 1990. The detrimental effects of air on silage. J. Appl. Bacteriol. 68:101-116.

Wu-Tai, G., F. Driehuis, and P. van. Wikselaar. 2002. The influence of addition of sugar with or without $L$. buchneri on fermentation and aerobic stability of whole crop maize silage ensiled under anaerobic silos. Asian-Australas. J. Anim. Sci. 15:1128-1133. 